BENM 2021

International Scientific and Practical Conference "Biotechnology, Ecology, Nature Management"

\title{
DISEASES OF RODENTS DANGEROUS TO HUMANS FOUND IN URBANIZED ECOSYSTEMS
}

\author{
Viktoriya V. Erofeeva (a)*, Sergey L. Yablochnikov (b), Olga V. Maslennikova (c), \\ Maksim N. Mahiboroda (d) \\ *Corresponding author \\ (a) Moscow Technical University of Communications and Informatics, Moscow, Russian Federation; \\ Peoples ' Friendship University of Russia, Moscow, Russian Federation, \\ erofeeva-viktori@mail.ru \\ (b) Moscow Technical University of Communications and Informatics, Moscow, Russian Federation, \\ vvkfek@mail.ru \\ (c) Vyatka State Agricultural Academy, Kirov, Russian Federation, olgamaslen@yandex.ru \\ (d) Academy of the FPS of Russia, Ryazan, Russian Federation, maks-net@yandex.ru
}

\begin{abstract}
The article analyzes zoonoses - diseases transmitted to humans from rodents. The object of the study were rodents in urbanized ecosystems of Kirov-city from 2018 to 2020. The relevance of this topic is due to the fact that in the Kirov region, where the studies were conducted, the helminth fauna of rodents of residential areas has not been studied. All rodents were examined by full helminthological autopsy according to Skryabin's methods. A total of 183 rodent carcasses were subjected to full biological analysis. As a result of the research it was found out that synanthropic and other species of rodents in urbanized ecosystems of Kirov region are involved in the spread of the following zoonoses which are dangerous for people (Toxocariasis, Alariosis). The dominant species of rodents in urbanized ecosystems of Kirov region were identified: Mus muskulus, Rattus norvegicus, Clethrionomys glareolus The Microtus arvalis sp., as an invasive species in the area, had the highest species composition of parasitic worms (9 species). The analysis of the helminth fauna of rodents resulted in the conclusion about specificity of some helminth species in certain rodent species, which is expressed in polygonality, i.e., it can be regarded as ecological adaptation of helminthes in relation to this group of hosts.
\end{abstract}

2672-8575 @ 2022 Published by European Publisher.

Keywords: Diseases, helminthiasis, synanthropic rodents, urbanized ecosystems, zoonoses 


\section{Introduction}

An amount of parasitic diseases and infections transmitted by rodents to humans is very high (Arkhipov et al., 2005; Luneva \& Ponomarev, 2014). Rodents living both in human housing and in other structures near people (garages, garden plots), as well as in natural conditions outside settlements are carriers and reservoirs of pathogens of a number of infections and helminths. Such rodents are: Mus muskulus, Rattus norvegicus, Apodemus agrarius, Apodemus uralensis, Microtus arvalis sp., Clethrionomys glareolus, Clethrionomys rutilus. In recent decades, in urbanized ecosystems, pollution of the environment by helminth eggs of stray and domestic animals, as well as synanthropic and other rodent species has become a big problem. According to modern studies, the parasitic "pollution" of the environment of urbanized ecosystems is increasing. Helminths, which are transmitted to humans from rodents, play not the least role in this. Rodents are the final, additional or intermediate hosts of many helminths, whose sexually mature forms can parasitize humans and animals, causing diseases of varying severity (Glebova et al., 2019; Martinich \& Stroll, 2020). In urbanized ecosystems of cities, humans repeatedly come into contact with rodents, which are reservoir hosts of many dangerous diseases (Shatokhin et al., 2019; Shishkanova, 2011). In the Kirov region, where the studies of rodent helminths fauna were conducted, it is practically not studied, which explains the relevance of the study. In megacities, rodents play the role of definitive and reservoir hosts of anthropozoonotic invasions (Zaichenko, 2012). Consequently, further study of rodent parasites and diseases that are dangerous to humans is required. As a consequence, monitoring is required to control known parasitic worms that cause disease in humans.

The absence of comprehensive helminthological studies considering the totality of endoparasites of rodents was the main motivation for the present work.

\section{Problem Statement}

In recent decades, biological contamination of the environment by helminth eggs of domestic animals as well as small mammals has become a major environmental problem in metropolitan areas. The environment is the main source of human contamination, with an annual accumulation of large amounts of invasive material. In light of the data on parasitic "pollution" of the environment, the study of small mammal helminthes becomes important, especially with regard to parasites dangerous for humans and animals. The study of rodent helminthes is of certain importance for the development of a number of questions of ecological parasitology. The diversity of lifestyles and habitat conditions of hosts has a great impact on the species composition of their helminths, which can parasitize humans as well. Rodents serve as final, additional or intermediate hosts of those helminths, the sexually mature and larval forms of which can parasitize in humans and animals, causing diseases of varying severity. All this illustrates the relevance of the study. 


\section{Research Questions}

The main research question is to identify the list of rodent diseases that pose a danger to humans, and to determine the types of rodent parasites that cause disease in humans.

\section{Purpose of the Study}

The aim of our study is to establish the role of rodents in the circulation of diseases dangerous to humans in urbanized ecosystems of the Kirov region.

\section{Research Methods}

The objects of the study were groups of rodents living in urbanized ecosystems in Kirov and its environs. A total of 183 rodent carcasses were subjected to full helminthological autopsy and biological analysis. The helminthological autopsy was performed according to the methods of K.I. Skryabin modified by Kotelnikov, (1984). Invasion extensiveness (EI) and invasion intensity (II) were calculated. The rodent composition studied included the following species: 41 Clethriomys glareolus; 30 Mus muskulus; 28 Microtus agvalis sp.; 25 Audra zibeticus; 8 Apodemus cornelensis; 7 Rattus norevicus; 6 Apodemus agrius; 4 Clethrionomys rutilus; 4 Sciurus vulgaris; 2 Agvicola terhestris, and 27 laboratory mice were also studied.

\section{Findings}

Species composition of helminths of rodents in urbanized ecosystems of Kirov requires further study. The species composition of rodent helminths in urbanized ecosystems of Kirov requires further study and clarification. As a result of our research 20 helminth species were found. They belong to two types: Platythelminthes and Nemathelminthes and are combined into three classes: Trematoda, Cestoda, Nematoda.

Infestation rate was the highest (87.5\%) in Rattus norvegicus, $71-75 \%$ in Microtus arvalis $s p$., Clethrionomys glareolus, Clethrionomys rutilus. Mus muskulus had a low infestation rate (13.3\%). No helminths were found in the Apodemus agrarius.

The highest number of parasitic worm species was found in the Microtus arvalis sp (9 species), 6 species in the Clethrionomys glareolus, 4 species in the Apodemus uralensis, 3 species each in the Rattus norvegicus, Mus muskulus, 2 species in the Ondatra zibeticus; 1 species in the Sciurus vulgaris. The results are shown in the Table 1.

Table 1. Rodent infestation with helminths

\begin{tabular}{|c|c|c|c|c|}
\hline Species & $\begin{array}{c}\text { Extensiveness of invasion. } \\
\text { EI }\end{array}$ & Trematoda & Cestoda & Nematoda \\
\hline Mus muskulus & $13,3 \%$ & - & 1 & 2 \\
\hline Rattus norvegicus & $85,7 \%$ & - & 1 & 2 \\
\hline Apodemus agrarius & 0 & - & - & - \\
\hline Apodemus uralensis & $62,5 \%$ & 1 & 1 & 2 \\
\hline
\end{tabular}




\begin{tabular}{ccccc}
\hline Microtus arvalis $s p$. & $72 \%$ & 1 & 4 & 4 \\
Clethrionomys glareolus & $71 \%$ & 1 & 2 & 3 \\
Clethrionomys rutilus & $75 \%$ & - & 1 & 2 \\
Ondatra zibeticus & $55,6 \%$ & 1 & 1 & - \\
Sciurus vulgaris & $25 \%$ & - & 1 & - \\
\hline
\end{tabular}

The low intensity of infestation in the Mus muskulus is explained by a large number of young animals $(53.3 \%)$, while in the rat only adults were investigated. At the same time, the extensiveness of infestation of young individuals in the Clethrionomys glareolus is significant. Two adult males and 7 juveniles of 41 investigated individuals of Clethrionomys glareolus were not infected; weight of the young ranged from 8.3 to $16.7 \mathrm{~g}$.

At present, the established equilibrium of both parasitic systems and their hosts is disturbed under the influence of various anthropogenic factors.

Helminthofaunistic complexes of synanthropic and other rodent species are sources of many anthropozoonoses dangerous for humans. When host and parasite numbers are high, there is considerable pollution as well as accumulation of invasive elements in urbanized ecosystems (Maslennikova \& Erofeeva, 2020). Therefore, parasites on the one hand are a natural component of natural ecosystems, and on the other hand - a factor of biological pollution of the environment. Rodents inhabiting near humans participate in the circulation of many helminth species having an important ecological and epidemiological significance.

In urbanized ecosystems of Kirov region there are 6 species of rodents whose helminths are dangerous for humans: nematodes of the genus Surhasia, Tochosaga sp., cestodes Hymenolepis diminuta and Hydatigera taeiniayeformis (Strobilocercus fasciolaris) and trematode Alaria alata. Parasites are involved in the formation of five anthropozoonoses in this territory. Data on rodent involvement in four zoonoses are given in Table 2.

Table 2. Results of rodent testing for infestation with helminths dangerous to humans

\begin{tabular}{|c|c|c|c|c|c|c|c|c|}
\hline \multirow[b]{2}{*}{ Species } & \multicolumn{2}{|c|}{$\begin{array}{l}\text { Hymenolepis } \\
\text { diminuta }\end{array}$} & \multicolumn{2}{|c|}{ Alaria alata } & \multicolumn{2}{|c|}{$\begin{array}{l}\text { Hydatigera } \\
\text { taeniaeformis }\end{array}$} & \multicolumn{2}{|c|}{ Syphacia sp. } \\
\hline & $\mathbf{n}$ & $(\%) E I$ & $\mathbf{n}$ & $(\%) E I$ & $\mathbf{n}$ & $(\%) E I$ & $\mathbf{n}$ & $(\%) \mathrm{EI}$ \\
\hline Mus muskulus & 30 & 0 & 30 & 0 & 30 & 3,3 & 30 & 3,3 \\
\hline $\begin{array}{c}\text { Rattus } \\
\text { norvegicus }\end{array}$ & 7 & 14,3 & 7 & 0 & 7 & 16,7 & 7 & 0 \\
\hline $\begin{array}{c}\text { Microtus } \\
\text { arvalis sp. }\end{array}$ & 28 & 20 & 28 & 4 & 28 & 12 & 28 & 21,4 \\
\hline $\begin{array}{c}\text { Clethrionomys } \\
\text { glareolus }\end{array}$ & 41 & 0 & 31 & 0 & 31 & 0 & 31 & 19,4 \\
\hline $\begin{array}{l}\text { Ondatra } \\
\text { zibeticus }\end{array}$ & 25 & 0 & 25 & 0 & 25 & 4 & 25 & 0 \\
\hline
\end{tabular}


In anthropogenic landscapes, as our studies have shown, in 6 species of rodents (Clethrionomys glareolus, Mus muskulus, Micontus agvalis sp., Ondatra zibeticus, Rattus norvegicus, Apodemus purensis) helminth species dangerous for humans were found.

The role of rodents is the most significant in cestode distribution. The tendency to the increase of this class of helminths has been noted in recent years (Maslennikova \& Erofeeva, 2020). In addition, rodents are important in trophic chains of predators, which emphasizes their importance in helminth distribution in carnivorous animals. Certain species of larval forms that cause severe diseases in humans (e.g., Hydatigera taeniaefomrmis and its larvae (Strobilocercus fasciolaris)) also have ecological and epidemiological significance.

We also found high intensity of invasion, which is characteristic of syphaea: 138 specimens were found in red-backed voles. We also found high infestation intensity, which is characteristic of syphations: in Clethrionomys glareolus we found 138 specimens of Shurasia petrusewiczi. The intestines of Microtus arvalis $s p$. had 44 specimens of Schurasia nigériana. Finding one hyperinvasive individual of the host significantly affects the average number of the parasite.

Having analyzed helminthofauna of mouse-like rodents, we can conclude about polygonicity, which can be regarded as ecological adaptation of helminthes in relation to this group of hosts.

Thus, as a result of our studies, it was found that the Mus muskulus is involved in two zoonoses: syphaciosis and strobilocerciasis; the Rattus norvegicus is also involved in two: hymenolepidosis and strobilocerciasis. The Clethrionomys glareolus and Ondatra zibeticus were involved in one: strobilocerciasis and syphaciasis, respectively. Only the Microtus arvalis sp. was involved in all 4 anthropozoonoses. In addition, the common vole and the forest mouse are involved in toxocariasis. Larval stages of Toxocara sp.

\section{Conclusion}

According to the results of the study the helminth fauna of rodents in anthropogenic landscapes was studied and the dominant species of rodents in urbanized ecosystems of Kirov region - Mus muskulus, Rattus norvegicus, Mus muskulus, Rattus norvegicus were identified.

The following species of parasitic worms found in rodents in urbanized areas were registered: nematodes Syphacia, Toxocara sp, cestodes Hymenolepis diminuta and Hydatigera taeniaeformis (Strobilocercus fasciolaris) and trematode Alaria alata are dangerous for humans and are involved in the maintenance of zoonosis: syphacyosis, toxocarosis, hymenolepidosis, hydatigerosis (strobilocercosis) and alariosis.

Thus, 6 species of rodents of anthropogenic landscapes are involved in zoonosis: Mus muskulus, Rattus norvegicus, Microtus arvalis sp., Clethrionomys glareolus, Ondatra zibeticus Apodemus uralensis. Laboratory mice are also dangerous. Most rodents are involved in one or two zoonotic diseases. The Microtus arvalis sp. is involved in all five. 


\section{References}

Arkhipov, I. A., Zeynalov, O. A., Kokorina, L. M., Avdanina, D. A., \& Likhotina, S. V. (2005). The spread of helminthiasis of dogs and cats in Russia and the use of a Prazitel to combat them. Russian Veterinary Journal, 2, 26-31.

Glebova, I. A., Nikiforov-Nikishin, D. L., Gorbunov, A. V., Kozlov, A. V., Gybina, T. G., Zaitseva, N. A., \& Larionova, A. A. (2019). Investigation of the Presence of Mutagens in the Coastal Part of Lake Senezh near the Highway. Ekoloji, 28(107), 385-390.

Kotelnikov, G. A. (1984). Helminthological studies of animals and the environment. Kolos.

Luneva, N., \& Ponomarev, N. (2014). Survival of Toxocara canis eggs in the south of Western Siberia by the example of Altai Territory. Bulletin Alt. GAU., 11, 130-133.

Martinich, A. P., \& Stroll, A. (2020). Epistemology. Encyclopedia Britannica. https://www.britannica.com/topic/epistemology

Maslennikova, O. V, \& Erofeeva, V. V. (2020). Biological contamination of soils in urbanized ecosystems by Toxocara sp. Eggs. E3S Web of Conferences, 169. https://doi.org/10.1051/e3sconf/202016904002

Shatokhin, M. V., Nikiforov-Nikishin, A. L., Romanenko, A. I., Lazareva, R. I., Golovacheva, N. A., \& Klimov, V. A. (2019). Russia and China peculiarities of cooperation in the field of economy and ecology. Proceedings of the 33rd International Business Information Management Association Conference, IBIMA 2019: Education Excellence and Innovation Management through Vision 2020 : 33, Education Excellence and Innovation Management through Vision 2020, Granada, 1011 April 2019. Granada, pp. 6048-6055.

Shishkanova, L. V. (2011). Toxocariasis in the south of Russia. Rostov Scientific Research. Institute of Microbiology and Parasitology, Rostov.

Zaichenko, I. (2012). Helminthiasis of carnivorous urban population. Veterinaria Kubani. 